\title{
Porównanie właściwości przeciwutleniających wybranych części maliny właściwej (Rubus idaeus) i jeżyny europejskiej (Rubus fruticosus)*
}

\section{Comparison of the antioxidant properties of selected parts of raspberry (Rubus idaeus) and blackberry (Rubus fruticosus)}

\author{
Joanna Zielonka-Brzezicka', Anna Nowak¹, Magdalena Zielińska², Adam Klimowicz ${ }^{1}$ \\ ${ }^{1}$ Pomorski Uniwersytet Medyczny w Szczecinie, Katedra i Zakład Chemii Kosmetycznej i Farmaceutycznej, al. Powstańców Wlkp. 72, 70-111 Szczecin \\ 2 Pomorski Uniwersytet Medyczny w Szczecinie, Absolwentka Kosmetologii, al. Powstańców Wlkp. 72, 70-111 Szczecin \\ $\triangle$ adklim@pum.edu.pl
}

\begin{abstract}
Introduction: Antioxidants contained in plant raw materials prevent oxidative stress, and reduce the degenerative effects of free radical reactions and damage caused by UV radiation. Antioxidant activity is exhibited, for example, in raspberry (Rubus idaeus), and blackberry (Rubus fruticosus), which have a high content of tannins, flavonoids, phenolic acids, vitamins and minerals. Materials and methods: The raw plant material consisted of fresh and dried leaves and fruits of raspberries and blackberries harvested in 2014. This material was extracted using a Soxhlet apparatus and by an ultrasound-assisted technique. To evaluate antioxidant activity DPPH and FRAP methods were used in the first year and DPPH and ABTS methods in the second year of the study.

Results: The highest antioxidant activity, evaluated by the DPPH method in 2015, was demonstrated by both raspberry and blackberry fresh leaf extracts, whereas the highest reductive ability, assessed by FRAP, was demonstrated in fresh and
\end{abstract}

\section{ABSTRAKT}

Wstę: Antyoksydanty zawarte w surowcach roślinnych zapobiegają stresowi oksydacyjnemu, redukując degeneracyjne skutki reakcji wolnorodnikowych czy uszkodzeń wywołanych promieniowaniem UV. Działanie przeciwutleniające wykazuja np. malina właściwa (Rubus idaeus) oraz jeżyna europejska (Rubus fruticosus), które charakteryzuja się wysoką zawartością tanin, flawonoidów, kwasów fenolowych oraz witamin i soli mineralnych.

Materiały i metody: Surowcem roślinnym były świeże i suszone liście oraz owoce maliny właściwej i jeżyny europejskiej zbierane w 2014 r., które ekstrahowano za pomocą aparatu Soxhleta i łaźni ultradźwiękowej. Oceny właściwości antyoksydacyjnych dokonano przy użyciu metody DPPH i FRAP w pierwszym roku oraz metody DPPH i ABTS w drugim roku badań.

Wyniki: Najwyższą aktywność przeciwutleniającą, przy zastosowaniu metody DPPH w 2015 r., wykazały ekstrakty ze świeżych liści zarówno maliny, jak i jeżyny, a zdolności redukcyjne, dried blackberry leaves. In the next year of the study (2016), the activity of samples evaluated using the DPPH method did not differ significantly, with the exception of fresh raspberry leaf. In this year, the highest antioxidant properties, assessed using the ABTS method, were shown by extracts made of fresh blackberry leaves and fruits, and dried blackberry leaves.

Conclusions: All the studied material, both ethanolic leaves and fruit extracts of raspberry and blackberry, reduced free radicals, which was examined using three methods of evaluation of the antioxidative properties (DPPH, FRAP and ABTS). The storage of ethanolic extracts at ambient temperature had no significant impact on the activity reduction of the evaluated plant material The antioxidant activity of most examined extracts remained consistently high, which may be reflected in the use of the studied materials as sources of antioxidants in the cosmetics and pharmaceuticals industries.

Keywords: antioxidant activity; plant extracts; DPPH; FRAP; ABTS.

oceniane metodą FRAP, świeże i suszone liście jeżyny. W następnym roku badań (2016) próby oznaczone metodą DPPH nie różniły się istotnie, z wyjątkiem świeżych liści maliny. W tym roku, oceniane przy wykorzystaniu metody ABTS, największymi właściwościami antyoksydacyjnymi charakteryzowały się ekstrakty ze świeżych liści i owoców jeżyny oraz suszonych liści jeżyny. Wnioski: Wszystkie badane wyciaggi etanolowe, zarówno z liści, jak i owoców maliny właściwej i jeżyny europejskiej, wykazywały aktywność antyoksydacyjną oznaczaną metodami: DPPH, FRAP, ABTS. Przechowywanie ekstraktów etanolowych w temperaturze otoczenia nie miało większego wpływu na obniżenie badanych właściwości surowca roślinnego. Aktywność przeciwutleniająca większości badanych ekstraktów utrzymywała się na wysokim poziomie, co może mieć przełożenie na wykorzystanie tych surowców jako źródeł przeciwutleniaczy w przemyśle kosmetycznym i farmaceutycznym.

Słowa kluczowe: aktywność antyoksydacyjna; ekstrakty roślinne; DPPH; FRAP; ABTS.

* W artykule wykorzystano m.in. wyniki zamieszczone w dwóch pracach magisterskich:

1) Joanna Zielonka, „Ekstrakty z jeżyny jako źródło antyoksydantów przydatnych w preparatach kosmetycznych osłabiających procesy starzenia się skóry” wykonanej w Zakładzie Farmakoterapii Dermatologicznej (obecnie Katedra i Zakład Chemii Kosmetycznej i Farmaceutycznej) Pomorskiego Uniwersytetu Medycznego w Szczecinie i obronionej na Wydziale Nauk o Zdrowiu PUM. Promotor: prof. dr hab. n. med. Adam Klimowicz. Oryginał zawiera: 78 stron, 28 rycin, 15 tabel, 62 pozycje piśmiennictwa.

2) Magdalena Zielińska, „Właściwości antyoksydacyjne etanolowych wyciągów z malin jako potencjalnych składników kosmetyków anti-aging” wykonanej w Zakładzie Farmakoterapii Dermatologicznej (obecnie Katedra i Zakład Chemii Kosmetycznej i Farmaceutycznej) Pomorskiego Uniwersytetu Medycznego w Szczecinie i obronionej na Wydziale Nauk o Zdrowiu PUM. Promotor: prof. dr hab. n. med. Adam Klimowicz. Oryginał zawiera: 50 stron, 9 rycin, 4 tabele, 46 pozycji piśmiennictwa. 


\section{WSTEP}

Większość wolnych rodników można zaliczyć do reaktywnych form tlenu, do których należą również nadtlenek wodoru oraz tlen singletowy [1, 2, 3]. Reaktywne formy tlenu mogą się tworzyć w wyniku procesów fizjologicznych, takich jak wzrost komórek, apoptoza, różnicowanie, autooksydacja lipidów czy oddychanie komórkowe, ale również wskutek procesów patologicznych, infekcji, reakcji immunologicznych i przy udziale szkodliwych czynników zewnętrznych $[1,4]$. Organizm ludzki posiada specyficzne mechanizmy enzymatyczne i nieenzymatyczne działające w celu ochrony przeciwrodnikowej i utrzymania równowagi redoks w komórkach organizmu. Pod wpływem pewnych czynników, zarówno egzo-, jak i endogennych, w przypadku niedostatecznej zdolności organizmu do eliminacji reaktywnych form tlenu, bilans ten zostaje zaburzony i dochodzi do tzw. zjawiska stresu oksydacyjnego. Może ono prowadzić do uszkodzeń struktur komórkowych, a w konsekwencji do różnych stanów chorobowych. Skutki, jakie przypisuje się nadmiarowi utleniaczy, obejmują m.in.: zmianę struktury i funkcji lipidów, białek, enzymów i struktur DNA, mutacje komórkowe, a w konsekwencji aktywację kaskady reakcji rodnikowych, które mogą pośrednio prowadzić do niekorzystnych procesów, np. do rozwoju miażdżycy tętnic, cukrzycy, zapalenia stawów, nowotworów oraz przedwczesnego starzenia się organizmu $[1,5,6]$. W celu ochrony przed wspomnianymi procesami wykorzystywane są związki zaliczane do grupy przeciwutleniaczy. Można je definiować jako cząsteczki zdolne do hamowania utleniania innych molekuł, chroniące organizm przed stresem oksydacyjnym. Działanie takie mogą wykazywać przeciwutleniacze obecne w tkankach ustroju, takie jak: witaminy C i E, ubichinon, karotenoidy, glutation, enzymy, w tym dysmutaza nadtlenkowa, katalaza, peroksydaza glutationu [7]. Właściwości antyrodnikowe posiadają również inne związki egzogenne należące do różnych grup, np.: polifenole z podgrupą flawonoidów (w tym katechiny, flawony, izoflawony, antocyjany, flawanony, flawanole), lignanów, stilbenów, karotenoidów (likopen, luteina, karoteny), jak również betalainy. Dodatkowo wspomnianymi własnościami wykazują się związki takie jak koenzym Q10, kwas ferulowy czy melatonina $[7,8]$.

Naturalna ochrona organizmu przed nadmiarem wolnych rodników może być niewystarczająca. Wskazuje to na konieczność współdziałania antyoksydantów różnego pochodzenia i o różnych mechanizmach działania [9]. Cennym naturalnym źródłem antyoksydantów dostarczanych z pożywieniem są niektóre warzywa, owoce, przyprawy i zioła $[3,8,10]$.

W piśmiennictwie można znaleźć wiele przykładów badań dotyczących właściwości przeciwutleniających owoców z uwagi na ich potencjał wynikający z obecności związków z grupy polifenoli. Na zainteresowanie zasługuje rodzina różowatych (Rosaceae), w tym rośliny z rodzaju Rubus z uwagi na ich szerokie zastosowanie i łatwą dostępność. Rodzaj ten obejmuje ok. 700 gatunków występujących naturalnie w klimacie umiarkowanym [11]. Surowce te znajdują zastosowanie w medycynie ludowej, niekonwencjonalnej, ale też w farmacji i kosmetyce.
Charakteryzują się one wysokimi wartościami odżywczymi, są bogate w taniny, flawonoidy, antocyjany, kwasy fenolowe, kwercetynę, triterpeny, witaminę C, E, kwas foliowy, błonnik, pektyny oraz sole mineralne. Wiele z tych składowych wykazuje działanie przeciwutleniające [11, 12, 13, 14, 15].

Obecnie obserwuje się tendencję do stosowania naturalnych surowców, które wykazują wielokierunkowe działanie. Antyoksydanty znajdują zastosowanie w pielęgnacji skóry dojrzałej, zmęczonej, ziemistej, dotkniętej objawami starzenia, ale również w odbudowywaniu bariery skórnej, zapobieganiu stresowi oksydacyjnemu, redukowaniu degeneracyjnych skutków procesów rodnikowych czy uszkodzeń wywołanych promieniowaniem UV. Ze względu na powyższe właściwości wciąż prowadzone są badania w kierunku wykorzystania przeciwutleniaczy pochodzenia roślinnego w kosmetologii $[16,17]$.

Celem pracy była ocena właściwości antyoksydacyjnych wyciągów uzyskanych ze świeżych i suszonych liści oraz owoców maliny właściwej (Rubus idaeus) i jeżyny europejskiej (Rubus fruticosus) przy zastosowaniu różnych metod ekstrakcji surowca roślinnego.

\section{MATERIAtY I METODY}

2,2-difenylo-1-pikrylohydrazyl (DPPH), 2,4,6-tri(2-pirydylo)-s-triazyna (TPTZ), kwas 6-hydroksy-2,5,7,8-tetrametylchromano-2-karboksylowy (troloks), kwas 2,2-azyno-bis(etylobenzotiazolino-6-sulfonowy) - ABTS pochodziły z firmy Sigma Aldrich (USA); siarczan(VI) żelaza(II) heksahydrat i chlorek żelaza(III) heptahydrat były produkcji Merck Darmstadt (Niemcy); kwas octowy 99,5\% cz.d.a, octan sodu bezwodny cz.d.a, kwas solny $36 \%$ cz.d.a pochodziły z firmy Chempur (Piekary Śląskie, Polska).

Surowiec roślinny stanowiły części krzewu maliny właściwej (Rubus idaeus) oraz jeżyny europejskiej (Rubus fruticosus). Owoce, liście dojrzałe oraz młode liście obu roślin pozyskane zostały z krzewów rosnących na terenie Szczecina i zbierane były w przypadku maliny w okresie od początku lipca do końca sierpnia 2014 r., natomiast w przypadku jeżyny od kwietnia do sierpnia 2014 r. Materiał $\mathrm{w}$ formie świeżej poddano ekstrakcji w aparacie Soxhleta, ponadto zastosowano metodę ekstrakcji wspomaganej ultradźwiękami w łaźni ultradźwiękowej przez 30 minut. Tymi samymi metodami pozyskano również ekstrakty z suszonych owoców i liści. Do analiz użyto 5\% ekstraktów w 70\% (v/v) etanolu. Do czasu badania ekstrakty przechowywano szczelnie zamknięte $\mathrm{w}$ zaciemnionym miejscu.

Analizy właściwości antyoksydacyjnych dokonano przy użyciu trzech metod. Na początku 2015 r. badano aktywność przeciwrodnikową przy użyciu rodnika DPPH oraz zdolność redukcji jonów żelaza $\mathrm{Fe}^{3+}$ metodą FRAP. Pierwsze oznaczenia dokonano nieznacznie zmodyfikowaną metodą DPPH [18, $19,20,21]$. W tym przypadku jako materiał odniesienia został użyty etanolowy roztwór troloksu. Na podstawie zawartości niezredukowanego DPPH w badanej próbie, która jest odwrotnie proporcjonalna do stężenia antyoksydantu, wykreślono krzywą wzorcową. Dla poszczególnych prób obliczono równoważniki stężeń troloksu, jakim odpowiadają badane ekstrakty. 
Oznaczono również zdolność do eliminacji wolnych rodników RSA (radical scavenging activity - \%), korzystając ze wzoru:

$$
R S A[\%]=\left(1-\frac{A_{p}}{A_{o}}\right) \cdot 100 \%
$$

gdzie $A_{p}$ oznacza absorbancję próbki badanej, natomiast $A_{o}$ oznacza absorbancję próbki kontrolnej.

W przypadku metody FRAP analizowano zdolność badanych próbek do redukcji jonów żelaza $\mathrm{Fe}^{3+} \mathrm{z}$ kompleksu żelazowo-2,4,6-tri(2-pirydylo)-s-triazyny. Jako materiał odniesienia został użyty roztwór siarczanu(VI) żelaza(II). Oznaczeń dokonano nieznacznie zmodyfikowaną metodą FRAP [21, 22].

Na początku 2016 r. próby przebadano ponownie metodą z użyciem rodnika DPPH w celu sprawdzenia trwałości ekstraktów, a ponadto wyciągi zbadano przy użyciu metody ABTS określającej zdolność neutralizacji wolnego rodnika kwasu 2,2-azyno-bis(etylobenzotiazolino-6-sulfonowego). Analogicznie, jak w przypadku pierwszych oznaczeń, jako materiał odniesienia został użyty etanolowy roztwór troloksu. Obliczono równoważniki stężeń troloksu, jakim odpowiadają badane ekstrakty oraz RSA, wykorzystując podany uprzednio wzór. Wszystkie pomiary wykonano w trzech powtórzeniach, wykorzystując zmodyfikowaną metodę ABTS [22, 23], z których wyliczono średnią arytmetyczną i odchylenie standardowe (SD).

Analizę statystyczną wyników przeprowadzono w programie Statistica 12, wykorzystując jedno- i dwuczynnikową analizę wariancji przy poziomie istotności $\alpha=0,05$. Różnice międzygrupowe oceniano testem Tuckeya, $\mathrm{n}=3$.

\section{WYNIKI}

W tabeli 1 przedstawiono wyniki badań z 2015 r. przeprowadzonych z wykorzystaniem dwóch metod stosowanych do pomiaru właściwości antyoksydacyjnej. W przypadku metody DPPH zamieszczono średnie wartości ( $₫$ SD) aktywności antyoksydacyjnej wyrażone jako procent RSA oraz odpowiadające im stężenia troloksu w mmol/ $\mathrm{dm}^{3}$. W przypadku metody FRAP w tabeli 1 przedstawiono wyniki pomiaru aktywności antyoksydacyjnej jako zdolność redukcji jonów $\mathrm{Fe}^{3+}$ wyrażonej w postaci stężenie $\mathrm{FeSO}_{4}$.

Aktywność antyoksydacyjna liści i owoców maliny oraz jeżyny, oznaczona metodą DPPH, wyrażona jako procent RSA, mieściła się w granicach od 33,16 $\pm 1,27 \%$ do 99,32 $\pm 1,79 \%$ dla ekstraktów etanolowych uzyskanych przy użyciu aparatu Soxhleta oraz od 32,39 $\pm 0,69 \%$ do 97,60 $\pm 1,09 \%$ dla ekstraktów uzyskanych przy pomocy łaźni ultradźwiękowej. W przypadku surowców ekstrahowanych w aparacie Soxhleta najwyższymi właściwościami przeciwutleniającymi charakteryzowały się świeże liście maliny, gdzie aktywność antyoksydacyjna, wyrażona współczynnikiem RSA, wynosiła aż 99,32 \$1,79\%. Również wysoką aktywnością antyoksydacyjną charakteryzowały się świeże liście i owoce jeżyny, w przypadku których RSA wynosił odpowiednio 83,09 $\pm 0,29 \%$ i 85,15 $\pm 1,08 \%$, co różniło się istotnie od pozostałych wariantów. Istotnie najmniejszą aktywnością antyoksydacyjną w przypadku zastosowania aparatu Soxhleta charakteryzowały się świeże i suszone owoce maliny, osiągając współczynnik RSA na poziomie odpowiednio $29,98 \pm 2,31 \%$ oraz $33,16 \pm 1,27 \%$. W przypadku ekstraktów uzyskanych z wykorzystaniem ultradźwięków w metodzie DPPH zaobserwowano podobną tendencję, przy czym najwyższe właściwości przeciwrodnikowe wykazywały świeże liście maliny (97,60 $\pm 1,09 \%$ ), następnie świeże i suszone liście jeżyny (odpowiednio 89,47 $\pm 0,41 \%$ i 87,28 $\pm 0,48 \%$ ), zaś najniższe suszone owoce maliny, w przypadku których RSA wynosił 32,39 $\pm 0,69 \%$, oraz suszone owoce jeżyny - 38,22 $\pm 0,92 \%$. Aktywność antyoksydacyjna badana metodą FRAP, wyrażona jako zdolność redukcji jonów żelaza, dla badanych surowców uzyskanych przy użyciu aparatu Soxhleta mieściła się w przedziale od 10,28 $\pm 0,10 \mathrm{mmol} \mathrm{Fe}{ }^{2+} / \mathrm{L}$ w suszonych liściach jeżyny, które charakteryzowały się istotnie najwyższą aktywnością, do 1,00 $\pm 0,05 \mathrm{mmol} \mathrm{Fe}^{2+} / \mathrm{L}$ w suszonych owocach maliny. W przypadku ultradźwięków wystąpiła podobna tendencja, gdyż suszone liście jeżyny cechowały się właściwościami przeciwrodnikowymi na wysokim poziomie 7,16 $\pm 0,02 \mathrm{mmol} \mathrm{Fe}^{2+} / \mathrm{L}$, zaś suszone owoce maliny - 0,63 $\pm 0,02 \mathrm{mmol} \mathrm{Fe}^{2+} / \mathrm{L}$ (tab. 1).

W tabeli 2 przedstawiono wyniki pomiaru właściwości antyoksydacyjnej w drugim roku badań (2016), w którym powtórzono, w celu sprawdzenia trwałości wyciągów, oznaczenie metodą DPPH. Po roku przechowywania ekstraktów etanolowych w zaciemnionym miejscu i w temperaturze pokojowej w większości analizowanych prób właściwości przeciwutleniające mierzone metodą DPPH zmniejszyły się nieznacznie (wyjątek stanowiły świeże liście maliny) - rycina 1, dlatego też dodatkowo podjęto próbę oznaczenia aktywności sporządzonych wyciągów metodą ABTS. W przypadku tej metody istotnie najwyższą aktywnością antyoksydacyjną wyrażoną współczynnikiem RSA charakteryzowały się świeże i suszone liście jeżyny (odpowiednio 93,89 $\pm 2,75 \%$ i 93,51 $\pm 0,71 \%$ ) oraz świeże owoce jeżyny $(84,91 \pm 5,65 \%)$ dla prób uzyskanych przy użyciu aparatu Soxhleta. Podobna sytuacja wystąpiła dla ekstraktów uzyskanych z użyciem ultradźwięków. Suszony liść jeżyny charakteryzował się najwyższym współczynnikiem RSA na poziomie $94,36 \pm 1,36 \%$, następnie kolejno świeży liść jeżyny - 82,66 $\pm 2,49 \%$, świeży owoc jeżyny - 46,23 $\pm 4,80 \%$ oraz świeży liść maliny $-35,51 \pm 3,55 \%$. W metodzie tej istotnie najniższe właściwości przeciwutleniające wykazywały świeże i suszone owoce maliny, zarówno dla prób ekstrahowanych przy wykorzystaniu aparatu Soxhleta, jak i ultradźwięków, gdzie ich aktywność antyoksydacyjna mieściła się w granicach od $3,21 \pm 0,74 \%$ do $5,72 \pm 2,52 \%$.

Na rycinie 2 przedstawiono korelacje pomiędzy wartościami aktywności przeciwutleniającej uzyskanych opisanymi metodami w kolejnych latach badań. Wyniki dotyczą ekstraktów otrzymanych z wykorzystaniem aparatu Soxhleta oraz ultradźwięków. Wykazano wysoce istotną zależność pomiędzy wynikami uzyskanymi w latach 2015 i 2016 w metodzie DPPH; współczynnik korelacji Spearmana wynosił $r=0,982$ $(\mathrm{p}<0,001)$ dla ekstraktów uzyskiwanych z użyciem aparatu Soxhleta oraz $r=0,984(p<0,001)$ dla ekstraktów uzyskiwanych za pomocą łaźni ultradźwiękowej. Wysoką korelacją charakteryzowały się również wyniki otrzymane metodami DPPH 
TABELA 1. Właściwości przeciwutleniające ekstraktów etanolowych otrzymanych z liści i owoców maliny właściwej oraz jeżyny europejskiej oceniane metodami DPPH i FRAP w 2015 r., średnia \pm odchylenie standardowe

\begin{tabular}{|c|c|c|c|c|}
\hline \multirow{3}{*}{ Badany surowiec } & \multicolumn{4}{|c|}{ Metoda DPPH } \\
\hline & \multicolumn{2}{|c|}{ ekstrakcja za pomocą aparatu Soxhleta } & \multicolumn{2}{|c|}{ ekstrakcja wspomagana ultradźwiękami } \\
\hline & $\begin{array}{c}\text { aktywność } \\
\text { antyoksydacyjna (\% RSA) }\end{array}$ & $\begin{array}{l}\text { równoważnik troloksu } \\
(\mathrm{mmol} / \mathrm{L})\end{array}$ & $\begin{array}{c}\text { aktywność } \\
\text { antyoksydacyjna (\% RSA) }\end{array}$ & $\begin{array}{l}\text { równoważnik troloksu } \\
(\mathrm{mmol} / \mathrm{L})\end{array}$ \\
\hline Świeże liście maliny & $99,32 \pm 1,79 \mathrm{a}$ & $0,89 \pm 0,02 \mathrm{a}$ & $97,60 \pm 1,09 \mathrm{a}$ & $0,87 \pm 0,01 \mathrm{a}$ \\
\hline Świeże liście jeżyny & $83,09 \pm 0,29 b$ & $0,74 \pm 0,01 b$ & $89,47 \pm 0,41 b$ & $0,80 \pm 0,01 b$ \\
\hline Świeże owoce maliny & $29,98 \pm 2,31 \mathrm{f}$ & $0,27 \pm 0,02 \mathrm{e}$ & $41,20 \pm 1,55$ e & $0,38 \pm 0,01 \mathrm{e}$ \\
\hline Świeże owoce jeżyny & $85,15 \pm 1,08 b$ & $0,76 \pm 0,01 b$ & $61,57 \pm 0,70 \mathrm{~d}$ & $0,55 \pm 0,01 d$ \\
\hline Suszone liście maliny & $73,37 \pm 0,65 d$ & $0,68 \pm 0,01 c$ & $76,73 \pm 0,45 c$ & $0,71 \pm 0,01 \mathrm{c}$ \\
\hline Suszone liście jeżyny & $77,10 \pm 0,16 c$ & $0,69 \pm 0,00 \mathrm{c}$ & $87,28 \pm 0,48 b$ & $0,78 \pm 0,01 b$ \\
\hline Suszone owoce maliny & $33,16 \pm 1,27 \mathrm{f}$ & $0,30 \pm 0,01 \mathrm{e}$ & $32,39 \pm 0,69 \mathrm{~g}$ & $0,29 \pm 0,01 \mathrm{~g}$ \\
\hline Suszone owoce jeżyny & $52,24 \pm 0,39 \mathrm{e}$ & $0,46 \pm 0,01 \mathrm{~d}$ & $38,22 \pm 0,92 f$ & $0,33 \pm 0,01 \mathrm{f}$ \\
\hline \multirow{3}{*}{ Badany surowiec } & \multicolumn{4}{|c|}{ Metoda FRAP } \\
\hline & \multicolumn{2}{|c|}{ ekstrakcja za pomocą aparatu Soxhleta } & \multicolumn{2}{|c|}{ ekstrakcja wspomagana ultradźwiękami } \\
\hline & \multicolumn{2}{|c|}{$\begin{array}{l}\text { aktywność antyoksydacyjna } \\
\left(\mathrm{mmol} \mathrm{Fe}{ }^{3+} / \mathrm{L}\right)\end{array}$} & \multicolumn{2}{|c|}{$\begin{array}{c}\text { aktywność antyoksydacyjna } \\
\left(\mathrm{mmol} \mathrm{Fe}{ }^{3+} / \mathrm{L}\right)\end{array}$} \\
\hline Świeże liście maliny & \multicolumn{2}{|c|}{$3,52 \pm 0,08 d$} & \multicolumn{2}{|c|}{$1,92 \pm 0,03 c$} \\
\hline Świeże liście jeżyny & \multicolumn{2}{|c|}{$8,00 \pm 0,03 b$} & \multicolumn{2}{|c|}{$3,56 \pm 0,06 b$} \\
\hline Świeże owoce maliny & \multicolumn{2}{|c|}{$1,22 \pm 0,04 \mathrm{fg}$} & \multicolumn{2}{|c|}{$0,85 \pm 0,04 \mathrm{e}$} \\
\hline Świeże owoce jeżyny & \multicolumn{2}{|c|}{$4,24 \pm 0,05 c$} & \multicolumn{2}{|c|}{$1,81 \pm 0,02 \mathrm{c}$} \\
\hline Suszone liście maliny & \multicolumn{2}{|c|}{$1,98 \pm 0,14 \mathrm{e}$} & \multicolumn{2}{|c|}{$1,52 \pm 0,08 d$} \\
\hline Suszone liście jeżyny & \multicolumn{2}{|c|}{$10,28 \pm 0,10 a$} & \multicolumn{2}{|c|}{$7,16 \pm 0,02 \mathrm{a}$} \\
\hline Suszone owoce maliny & \multicolumn{2}{|c|}{$1,00 \pm 0,05 \mathrm{~g}$} & \multicolumn{2}{|c|}{$0,63 \pm 0,02 \mathrm{f}$} \\
\hline Suszone owoce jeżyny & 1,67 & 6 ef & \multicolumn{2}{|c|}{$0,84 \pm 0,03 \mathrm{e}$} \\
\hline
\end{tabular}

Wartości średnie oznaczone różnymi literami w kolumnach różnią się istotnie statystycznie $(\alpha=0,05), \mathrm{n}=3$.

TABELA 2. Właściwości przeciwutleniające ekstraktów etanolowych otrzymanych z liści i owoców maliny właściwej oraz jeżyny europejskiej oceniane metodami DPPH i ABTS w 2016 r., średnia £odchylenie standardowe

\begin{tabular}{|c|c|c|c|c|}
\hline \multirow{3}{*}{ Badany surowiec } & \multicolumn{4}{|c|}{ Metoda DPPH } \\
\hline & \multicolumn{2}{|c|}{ ekstrakcja za pomocą aparatu Soxhleta } & \multicolumn{2}{|c|}{ ekstrakcja wspomagana ultradźwiękami } \\
\hline & $\begin{array}{c}\text { aktywność } \\
\text { antyoksydacyjna (\% RSA) }\end{array}$ & $\begin{array}{l}\text { równoważnik troloksu } \\
(\mathrm{mmol} / \mathrm{L})\end{array}$ & $\begin{array}{c}\text { aktywność } \\
\text { antyoksydacyjna (\% RSA) }\end{array}$ & $\begin{array}{l}\text { równoważnik troloksu } \\
(\mathrm{mmol} / \mathrm{L})\end{array}$ \\
\hline Świeże liście maliny & $85,71 \pm 0,85 \mathrm{a}$ & $0,73 \pm 0,01 a$ & $86,20 \pm 0,49 a$ & $0,74 \pm 0,01 \mathrm{a}$ \\
\hline Świeże liście jeżyny & $82,84 \pm 0,87 a$ & $0,71 \pm 0,01 \mathrm{a}$ & $88,33 \pm 0,26 a$ & $0,76 \pm 0,01 \mathrm{a}$ \\
\hline Świeże owoce maliny & $23,20 \pm 3,15 f$ & $0,18 \pm 0,03 \mathrm{f}$ & $35,08 \pm 3,90 \mathrm{c}$ & $0,28 \pm 0,04 \mathrm{C}$ \\
\hline Świeże owoce jeżyny & $84,79 \pm 0,89 a$ & $0,72 \pm 0,01 \mathrm{a}$ & $60,65 \pm 2,99 b$ & $0,51 \pm 0,03 b$ \\
\hline Suszone liście maliny & $65,52 \pm 2,77 \mathrm{c}$ & $0,55 \pm 0,03 c$ & $80,50 \pm 6,33 a$ & $0,69 \pm 0,06 a$ \\
\hline Suszone liście jeżyny & $73,31 \pm 0,71 b$ & $0,62 \pm 0,01 b$ & $86,09 \pm 0,26 \mathrm{a}$ & $0,74 \pm 0,01 \mathrm{a}$ \\
\hline Suszone owoce maliny & $31,17 \pm 3,90 \mathrm{e}$ & $0,25 \pm 0,03 \mathrm{e}$ & $29,63 \pm 4,86 c$ & $0,24 \pm 0,05 c$ \\
\hline Suszone owoce jeżyny & $51,58 \pm 2,73 d$ & $0,43 \pm 0,02 \mathrm{~d}$ & $38,69 \pm 1,53 c$ & $0,32 \pm 0,02 c$ \\
\hline \multirow{2}{*}{ Badany surowiec } & \multicolumn{4}{|c|}{ Metoda ABTS } \\
\hline & $\begin{array}{c}\text { aktywność } \\
\text { antyoksydacyjna (\% RSA) }\end{array}$ & $\begin{array}{l}\text { równoważnik troloksu } \\
(\mathrm{mmol} / \mathrm{L})\end{array}$ & $\begin{array}{c}\text { aktywność } \\
\text { antyoksydacyjna (\% RSA) }\end{array}$ & $\begin{array}{l}\text { równoważnik troloksu } \\
(\mathrm{mmol} / \mathrm{L})\end{array}$ \\
\hline Świeże liście maliny & $73,26 \pm 5,88 b$ & $2,16 \pm 0,17 a$ & $35,51 \pm 3,55 b$ & $1,12 \pm 0,10 b$ \\
\hline Świeże liście jeżyny & $93,89 \pm 2,75 \mathrm{a}$ & $2,73 \pm 0,08 a$ & $82,66 \pm 2,49 a$ & $2,42 \pm 0,07 a$ \\
\hline Świeże owoce maliny & $3,21 \pm 0,74 \mathrm{~d}$ & $0,23 \pm 0,02 c$ & $5,72 \pm 2,52 \mathrm{~d}$ & $0,30 \pm 0,07 \mathrm{~cd}$ \\
\hline Świeże owoce jeżyny & $84,91 \pm 5,65 \mathrm{a}$ & $2,48 \pm 0,16 a$ & $46,23 \pm 4,80 b$ & $1,41 \pm 0,13 b$ \\
\hline Suszone liście maliny & $34,59 \pm 1,57 \mathrm{c}$ & $1,09 \pm 0,04 b$ & $8,71 \pm 4,60 \mathrm{~d}$ & $0,38 \pm 0,13 \mathrm{~cd}$ \\
\hline Suszone liście jeżyny & $93,51 \pm 0,71 \mathrm{a}$ & $2,71 \pm 0,02 \mathrm{a}$ & $94,36 \pm 1,36 a$ & $2,74 \pm 0,04 a$ \\
\hline Suszone owoce maliny & $3,27 \pm 2,14 \mathrm{~d}$ & $0,23 \pm 0,06 c$ & $3,76 \pm 1,28 \mathrm{~d}$ & $0,24 \pm 0,04 \mathrm{~d}$ \\
\hline Suszone owoce jeżyny & $35,29 \pm 2,55 c$ & $1,11 \pm 0,07 \mathrm{~b}$ & $24,64 \pm 2,14 \mathrm{C}$ & $0,82 \pm 0,06 \mathrm{c}$ \\
\hline
\end{tabular}

Wartości średnie oznaczone różnymi literami w kolumnach różnią się istotnie statystycznie $(\alpha=0,05), \mathrm{n}=3$. 

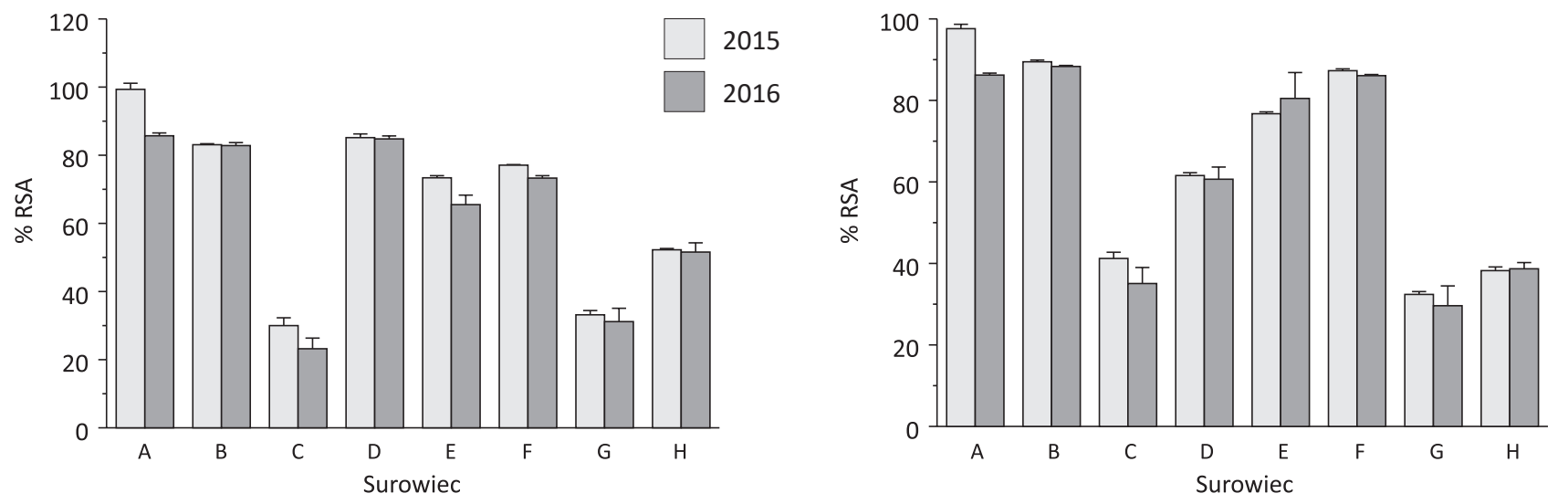

A - świeże liście maliny; B - świeże liście jeżyny; C - świeże owoce maliny; D - świeże owoce jeżyny; E - suszone liście maliny; F - suszone liście jeżyny; G - suszone owoce maliny; $\mathrm{H}$ - suszone owoce jeżyny. Poziom istotności $\alpha=0,05, \mathrm{n}=3$.

RYCINA 1. Porównanie aktywności antyoksydacyjnej oznaczonej metodą DPPH w latach 2015 i 2016 z wykorzystaniem dwóch metod ekstrakcji surowca (aparatu Soxhleta i ultradźwięków)
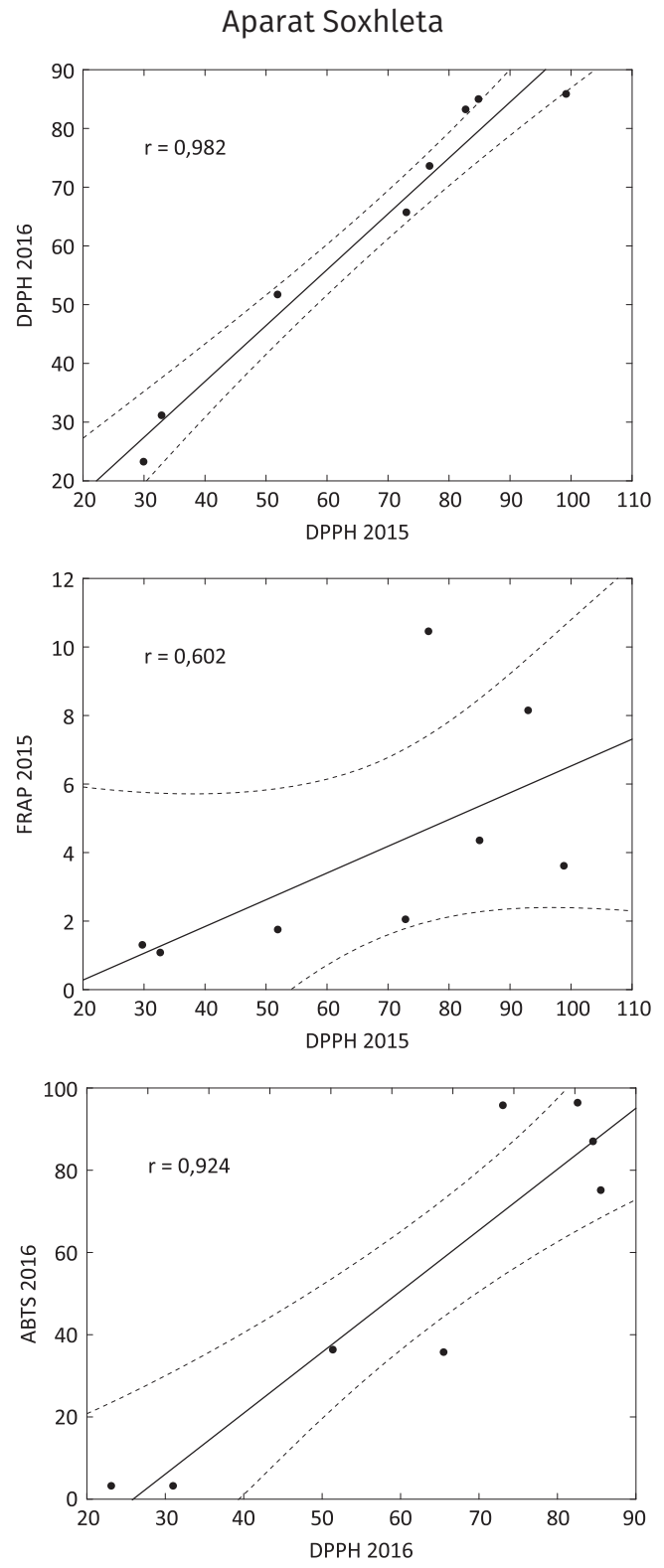

Ultradźwięki
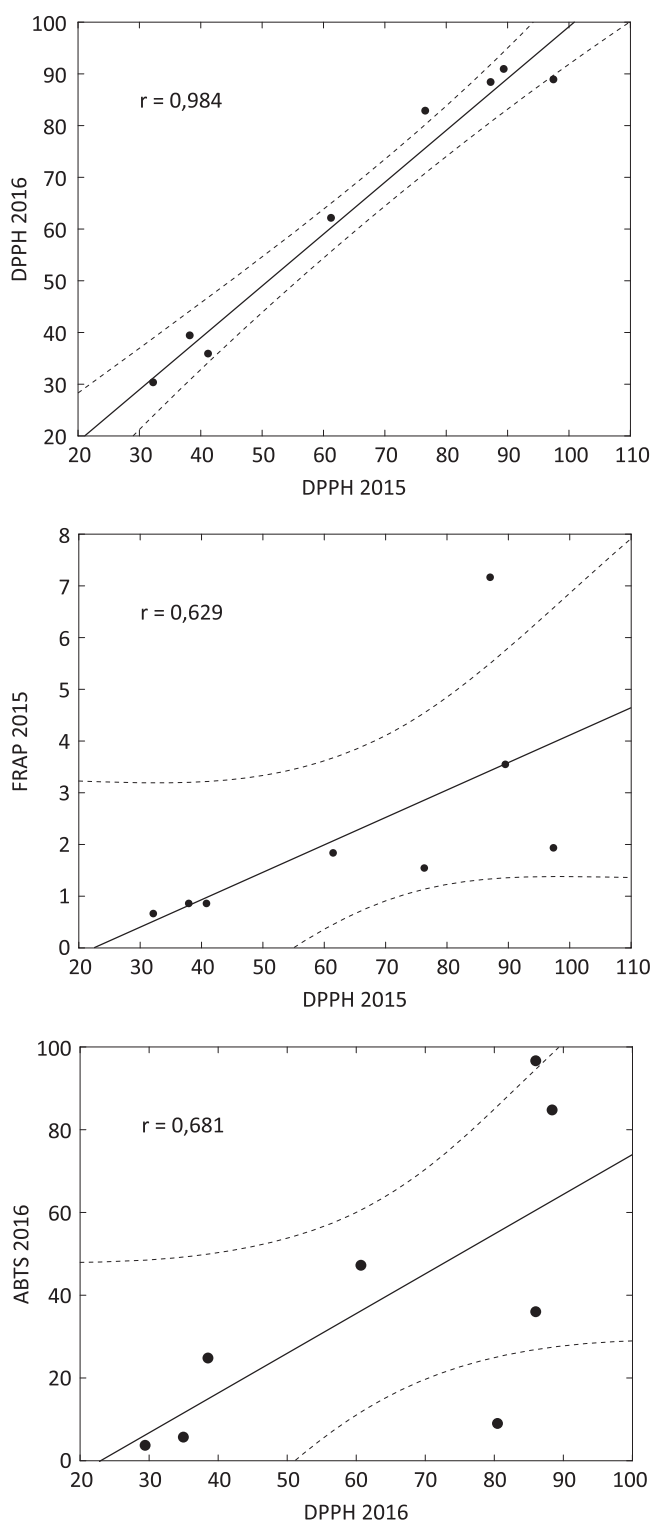

RYCINA 2. Korelacja pomiędzy wynikami uzyskanymi metodami DPPH, FRAP oraz ABTS w obydwu latach badań z wykorzystaniem aparatu Soxhleta oraz ultradźwięków 
i ABTS w 2016 r., w przypadku których współczynnik korelacji wynosił $\mathrm{r}=0,924(\mathrm{p}=0,001)$. Natomiast słabą zależność odnotowano, porównując metody FRAP z metodą DPPH w obydwu latach badań, co sugeruje współczynnik korelacji na poziomie $r=0,602$ w 2015 i r = 0,629 w 2016 r. Podobne wnioski można wysnuć, porównując oznaczenia metodą ABTS z metodą DPPH przeprowadzone w drugim roku badań $(r=0,681)$.

\section{DYSKUSJA}

W badaniach przeprowadzonych w 2015 i 2016 r. oznaczono aktywność antyoksydacyjną świeżych i suszonych liści i owoców maliny i jeżyny z wykorzystaniem trzech metod: DPPH, FRAP oraz ABTS, przy czym w pierwszym roku badań oceniano wyciągi metodami DPPH oraz FRAP, następnie po roku przechowywania prób - metodami DPPH i ABTS. Wyciągi etanolowe wszystkich surowców uzyskano, wykorzystując aparat Soxhleta oraz łaźnię ultradźwiękową. Na podstawie przeprowadzonych badań można stwierdzić, że wyciągi etanolowe liści i owoców jeżyny oraz maliny wykazują zdolności do redukcji wolnych rodników, co potwierdzono wszystkimi trzema metodami oznaczenia (tab. 1 i 2). Aktywność ta była różna w zależności od rodzaju badanego surowca oraz metody oznaczania właściwości antyoksydacyjnych, przy czym najwyższe zdolności przeciwutleniające wyrażone współczynnikiem RSA (\%) przy zastosowaniu metody DPPH w 2015 r. wykazały świeże liście zarówno maliny, jak i jeżyny, a także świeże owoce jeżyny, gdzie uzyskano wynik wskazujący na bardzo wysokie właściwości przeciwrodnikowe - ponad 87\%, zaś w przypadku świeżych liści malin nawet ponad 99\% (tab. 1). W następnym roku badań (2016) próby oznaczone metodą DPPH nie różniły się istotnie, z wyjątkiem świeżych liści maliny (ryc. 1, tab. 2). W tym roku oceniane przy wykorzystaniu metody ABTS istotnie najwyższe wartości RSA miały otrzymane przy użyciu aparatu Soxhleta ekstrakty ze świeżych liści $(93,89 \%)$, owoców jeżyny $(84,91 \%)$ i suszonych liści jeżyny $(93,51 \%)$ oraz uzyskane z zastosowaniem łaźni ultradźwiękowej wyciągi ze świeżych $(82,66 \%)$ i suszonych liści jeżyny (94,36\%) - tabela 2.

Właściwości antyoksydacyjne surowców roślinnych związane są z wysoką zawartością niektórych związków, jak np. polifenoli z obszerną podgrupą flawonoidów (w tym katechiny, flawony, izoflawony, antocyjany, flawanony, flawanole), a także kwasów fenolowych, lignanów i stilbenów. Kolejne grupy to karotenoidy (likopen, luteina, karoteny), betalainy, witaminy. Dodatkowo wspomnianymi własnościami wykazują się związki takie jak koenzym Q10, kwas ferulowy czy melatonina $[7,8]$. Emmons i wsp. oraz Kołodziej i Drożdżal zaobserwowali w swoich badaniach dotyczących ekstraktów z owsa zwyczajnego oraz kwiatów i owoców bzu czarnego dodatnią korelację pomiędzy zawartością polifenoli, związków fenolowych w roślinach i ich aktywnością antyoksydacyjną [24, 25]. Oancea i wsp. w badaniach wykazali znaczną ilość antocyjanin w etanolowych wyciągach z jeżyny, natomiast Tsanova-Savova i wsp. oraz Lim podają iż owoc jeżyny jest bogatym źródłem związków fenolowych w porównaniu z innymi produktami spożywczymi [14, 26, 27]. Natomiast Niculescu i wsp. stwierdzili w owocu jeżyny bardzo dużą zawartość takich antocyjanin, jak cyjanidyna i malwidyna, które mogą decydować o silnych właściwościach antyoksydacyjnych surowca [28].

Na właściwości przeciwutleniające może też mieć wpływ świeżość badanego surowca roślinnego. Po wysuszeniu surowców w badaniach własnych uzyskano wyniki niejednorodne, w zależności od zastosowanej metody oznaczania aktywności antyoksydacyjnej (tab. 1). Beyhan i wsp. badali metanolowe ekstrakty ze świeżych oraz suszonych owoców i liści akki sellowej [29]. Największą zdolnością przeciwutleniającą charakteryzowały się liście, natomiast 2-krotnie wyższą zawartość przeciwutleniaczy w grupie owoców wykazano w ekstraktach ze świeżego surowca. Odmienne wyniki podają Alabri i wsp., którzy uzyskali największą aktywność antyoksydacyjną w świeżych liściach surmikwiatu. Autorzy ci sugerują, że podczas przechowywania surowców roślinnych niektóre lotne związki mogą odparować i ulegać rozkładowi, natomiast uzyskany efekt jest uzależniony od wielu czynników, tj. rodzaju surowca czy metody przetwarzania próbek [30].

Wielu autorów zwraca uwagę na fakt, że właściwości utleniające surowców mogą ulec zmianie zależnie od sposobu i czasu ich przechowywania [31,32,33]. Odmienne wyniki uzyskano w badaniach własnych, gdyż różnice aktywności antyoksydacyjnej tych samych ekstraktów oznaczonych po upływie roku nie różniły się istotnie (ryc. 1, tab. 1 i 2).

Ważne znaczenie ma również wybór metody do oznaczania właściwości antyoksydacyjnej. Ruiz-Rodriguez i wsp. badali owoc tarniny i głogu jednoszyjkowego z wykorzystaniem metod DPPH i FRAP. Autorzy nie wskazali jednoznacznie, która z metod byłaby najlepsza, gdyż uzyskane przez nich wyniki różniły się istotnie. Sugerują oni jednak, że metoda DPPH może mieć większe znaczenie w oznaczaniu aktywności witaminy C, istotnego antyoksydantu, natomiast FRAP do oznaczania ogólnej zawartości polifenoli [34]. Z kolei Boeing i wsp. uzyskali największą zdolność przeciwutleniającą surowców (truskawek, morwy czarnej i jagód) ocenioną metodą redukcji jonów żelaza w porównaniu z analizą wykorzystującą rodnik DPPH i analizą zdolności absorbancji rodników tlenowych [35]. Potwierdzają to także przeprowadzone oznaczenia własne. Metoda FRAP, której zastosowanie ma na celu ocenę zdolności redukcji jonów $\mathrm{Fe}^{3+}$ przez badane ekstrakty, prowadziła do otrzymania nieco odmiennych wyników. W tym przypadku, jak i przy oznaczeniach z wykorzystaniem rodnika ABTS, najwyższą aktywność antyoksydacyjną wykazywały suszone liście jeżyny, natomiast w analizie z wykorzystaniem DPPH świeże liście jeżyny (tab. 1 i 2).

W przeprowadzonych badaniach aktywność antyoksydacyjna surowców była różna w zależności od zastosowanej metody ekstrakcji i nie można wskazać, który ze sposobów jest najkorzystniejszy. Do podobnych wniosków doszli Péres i wsp., którzy wskazali na rozbieżność w poziomie wyekstrahowanych substancji przeciwutleniających. Porównywali oni zawartość wybranych składowych w etanolowych ekstraktach z roślin z rodziny pieprzowatych, uzyskanych różnymi metodami. Zawartość witaminy E, będącej przeciwutleniaczem, 
była wyższa w wyciągach otrzymanych za pomocą aparatu Soxhleta niż w otrzymanych przy użyciu ultradźwięków [36]. Odmienne wyniki uzyskali Bimakr i wsp., badający beninkazę szorstką, bowiem stwierdzili znacznie wyższą aktywność antyoksydacyjną surowców uzyskanych za pomocą ekstrakcji wspomaganej ultradźwiękami [37].

Antyoksydanty działają w określony sposób: stabilizując i delokalizując niesparowane elektrony, poprzez chelatowanie jonów metali, jednocześnie unieczynniając enzymy utleniające, poprzez przerywanie reakcji rodnikowych, oddawanie elektronów w reakcjach redoks. Prowadzi to do neutralizacji i wychwytywania wolnych rodników przez przeciwutleniacze, które w ten sposób chronią struktury komórkowe przed utlenieniem, a co za tym idzie działają uszczelniająco na naczynia krwionośne, przeciwmutagennie i przeciwzapalnie. Można zatem oczekiwać ich przydatności w profilaktyce chorób układu krwionośnego, nerwowego, procesu fotostarzenia się skóry i uszkodzeń spowodowanych promieniowaniem UV, a także w łagodzeniu objawów alergii oraz klimakterium [3, 9, 38]. Aktywność antyoksydacyjna większości badanych ekstraktów utrzymywała się na wysokim poziomie, co może mieć przełożenie na wykorzystanie tych surowców jako źródeł przeciwutleniaczy w kosmetykach do skóry dojrzałej. Ponadto ze względu na zdolność do neutralizowania wolnych rodników jeżyna i malina mogą wspomagać naturalne mechanizmy obronne organizmu, chronić komórki przed utlenieniem i destrukcyjnym działaniem reakcji wolnorodnikowych, przyczyniających się do przedwczesnego starzenia się. Obecnie obserwuje się tendencję do stosowania naturalnych surowców, które wykazują wielokierunkowe działanie. Antyoksydanty znajdują zastosowanie w pielęgnacji skóry dojrzałej, zmęczonej, ziemistej, dotkniętej objawami starzenia, ale również w odbudowywaniu bariery skórnej, zapobieganiu stresowi oksydacyjnemu, redukowaniu degeneracyjnych skutków procesów rodnikowych czy uszkodzeń wywołanych promieniowaniem UV. Ze względu na powyższe właściwości wciąż prowadzone są badania w kierunku wykorzystania przeciwutleniaczy pochodzenia roślinnego w kosmetologii [16,17], zaś uzyskane wyniki badań własnych mogą być przyczynkiem do zastosowania ekstraktów z badanych roślin jako potencjalnych składników preparatów przeciwstarzeniowych.

\section{WNIOSKI}

1. Wszystkie badane ekstrakty roślinne uzyskane ze świeżych i suszonych liści oraz owoców maliny właściwej (Rubus idaeus) i jeżyny europejskiej (Rubus fruticosus) charakteryzowały się zdolnością do redukcji wolnych rodników.

2. Przechowywanie wyciągów etanolowych nie miało większego wpływu na obniżenie badanych właściwości surowca roślinnego.

3. Aktywność przeciwutleniająca większości badanych ekstraktów utrzymywała się na wysokim poziomie, co może sugerować wykorzystanie tych surowców jako źródeł przeciwutleniaczy w przemyśle kosmetycznym czy farmaceutycznym.

\section{PIŚMIENNICTWO}

1. Rezin GT, Andreazza AC. 7. Oxidative damage and its treatment impact. In: Yildiz A, Ruiz P, Nemeroff C, editors. The bipolar book: history, neurobiology, and treatment. Oxford: Oxford University Press; 2015. p. 83-92.

2. Gülçin I. Antioxidant activity of food constituents: an overview. Arch Toxicol 2012;86(3):345-91.

3. Nowak A, Zielonka J, Turek M, Klimowicz A. Wpływ przeciwutleniaczy zawartych w owocach na proces fotostarzenia się skóry. Post Fitoter 2014;2:94-9.

4. Kulbacka J, Saczko J, Chwiłkowska A. Stres oksydacyjny w procesach uszkodzenia komórek. Pol Merkur Lekarski 2009;27(157):44-7.

5. Prior RL. Oxygen radical absorbance capacity (ORAC): New horizons in relating dietary antioxidants/bioactives and health benefits. J Funct Foods 2015;18:797-810.

6. Valko M, Jomova K, Rhodes CJ, Kuča K, Musilek K. Redox- and non-redox-metal-induced formation of free radicals and their role in human disease. Arch Toxicol 2016;90(1):1-37.

7. Vinardell MP, Mitjans M. Nanocarriers for delivery of antioxidants on the skin. Cosmetics 2015;2:342-54.

8. Kałędkiewicz E, Lange E. Znaczenie wybranych związków pochodzenia roślinnego w diecie zapobiegającej chorobom nowotworowym. Post Fitoter 2013;(1):42-7.

9. Gryszczyńska B, Iskra M. Współdziałanie antyoksydantów egzogennych i endogennych w organizmie człowieka. Now Lek 2008;77(1): 50-5.

10. Embuscado ME. Spices and herbs: Natural sources of antioxidants - a mini review. J Funct Foods 2015;18:811-9.

11. Asnaashari M, Tajik R, Khodaparast MH. Antioxidant activity of raspberry (Rubusfruticosus) leaves extract and its effect on oxidative stability of sunflower oil. J Food Sci Technol 2015;52(8):5180-7. doi: 10.1007/ s13197-014-1564-7.

12. Da Fonseca Machado AP, Pasquel-Reátegui JL, Barbero GF, Martínez J. Pressurized liquid extraction of bioactive compounds from blackberry (Rubus fruticosus L.) residues: a comparison with conventional methods. Food Res Int 2015;77(3):675-83.

13. Kostecka-Gugała A, Ledwożyw-Smoleń I, Augustynowicz J, Wyżgolik G, Kruczek M, Kaszycki P. Antioxidant properties of fruits of raspberry and blackberry grown in central. Open Chem 2015;13:1313-25.

14. Lim TK. Rubus fruticosus agg. Edible medicinal and non-medicinal plants. Springer Netherlands 2012;4:544-52.

15. Baranowska A, Radwańska K, Zarzecka K, Gugała M, Mystkowska I. Właściwości prozdrowotne owoców maliny właściwej (Rubus idaeus L.). Probl Hig Epidemiol 2015;96(2):406-9.

16. Gianeti MD, Maia Campos P. Efficacy evaluation of a multifunctional cosmetic formulation: The benefits of a combination of active antioxidant substances. Molecules 2014;19:18268-82.

17. Ratz-Łyko A. Składniki aktywne pochodzenia roślinnego w kosmetykach anti-age. Cosmet Today Patents Inventions 2013;3:10-3.

18. Molyneux P. The use of stable free radical diphenylpicrylhydrazyl (DPPH) for estimating antioxidant activity. Songklanakarin J Sci Technol 2004;26(2):211-9.

19. Abderrahim F, Arribas SM, Gonzalez MC, Condezo-Hoyos L. Rapid highthroughput assay to assess scavenging capacity index using DPPH. Food Chem 2013;141(2):788-94. doi: 10.1016/j.foodchem.2013.04.055.

20. Ma Z, Cui F, Gao X, Zhang J, Zheng L, Jia L. Purification, characterization, antioxidant activity and anti-aging of exopolysaccharides by Flammulinavelutipes SF-06. Antonie Van Leeuwenhoek 2015;107(1):73-82. doi: 10.1007/s10482-014-0305-2.

21. Regulska E, Samsonowicz M. Ekstrakty ziołowe w aspekcie zawartości związków polifenolowych i aktywności przeciwutleniającej. In: Tarko T, Duda-Chodak A, Witczak M, Najgebauer-Lejko D, editors. Właściwości produktów i surowców żywnościowych. Kraków, Polskie Towarzystwo Technologów Żywności; 2014. p. 227-37.

22. Cybul M, Nowak R. Przegląd metod stosowanych w analizie właściwości antyoksydacyjnych wyciągów roślinnych. Herba Pol 2008;54(1): 68-78.

23. Do Thi N, Hwang E. Bioactive compound contents and antioxidant activity in aronia (Aronia melanocarpa) leaves collected at different growth stages. Prev Nutr Food Sci 2014;19(3):204-12. doi: 10.3746/pnf.2014.19.3.204. 
24. Emmons CL, Peterson DM, Paul GL. Antioxidant capacity of oats (Avena sativa L.) extracts. 2 . In vitro antioxidant activity and content of phenolic and total antioxidants. J Agric Food Chem 1999;47(12):4894-8.

25. Kołodziej B, Drożdżal K. Właściwości przeciwutleniające kwiatów i owoców bzu czarnego pozyskiwanego ze stanu naturalnego. Żywność Nauka Technologia Jakość 2011;4(77):36-44.

26. Oancea S, Grosu C, Ketney 0, Stoia M. Conventional and ultrasound-assisted extraction of anthocyanins from blackberry and sweet cherry cultivaes. Acta Chim Slov 2013;60(2):383-9.

27. Tsanova-Savova S, Petkov V, Vodenicharow E, Ribarowa F. Bulgarian traditional foods-sources of antioxidants. Acta Med Median 2003; 52:5-7.

28. Niculescu V, Paun N, Silion M, Popa MI. Anthocyanin profile of blackberries and grapes. Prog Cryog Isot Sep 2013;16(1):119-24.

29. Beyhan Ö, Elmastaş M, Gedikli F. Total phenolic compounds and antioxidant capacity of leaf, dry fruit and fresh fruit of feijoa (Acca sellowiana, Myrtaceae). J Med Plant Res 2010;4(11):1065-72.

30. Alabri THA, Al Musalami AHS, Hossain MA, Weli AM, Al-Riyami Q. Comparative study of phytochemical screening, antioxidant and antimicrobial capacities of fresh and dry leaves crude plant extracts of Datura metel L. J King Saud Univ Sci 2014;26(3):237-43.

31. Freeman BL, Stocks JC, Eggett DL, Parker TL. Antioxidant and phenolic changes across one harvest season and two storage conditions in primocane raspberries (Rubus idaeus L.) grown in a hot, dry climate. Hort Sci 2011;46(2):236-9.
32. Kalt W, Howell A, Duy JC, Forney CF, McDonald JE. Horticultural factors affecting antioxidant capacity of blueberries and other small fruit. Hort Technol 2001;11(4):523-8.

33. Piljac-Žegarac J, Šamec D. Antioxidant stability of small fruits in postharvest storage at room and refrigerator temperatures. Food Res Int 2011;44(1):345-50.

34. Ruiz-Rodriguez BM, Ancos B, Sanchez-Moreno C, Fernandez-Ruiz V, Cortel M, Mata S, et al. Wild blackthorn (Prunus spinosa L.) and hawthorn (Crataegus monogyna Jacq.) fruits as valuable sources of antioxidants. Fruits 2014;69(1):61-73.

35. Boeing JS, Barizão EO, Costa e Silva B, Montanher P, Almeida VC, Visentainer JV. Evaluation of solvent effect on the extraction of phenolic compounds and antioxidant capacities from the berries: application of principal component analysis. Chem Cent J 2014;8(1):48. doi: 10.1186/s13065-014-0048-1.

36. Péres VF, Melecchi MI, Abadc FC, de Assis Jacques R, Martinez MM, Oliveira EC, et al. Comparison of soxhlet, ultrasound-assisted and pressurized liquid extraction of terpenes, fatty acids and vitamin E from Piper gaudichaudianum Kunth. J Chromatogr A 2006;1105(1-2):115-8.

37. Bimakr M, Rahman RA, Taip FS, Adzahan NM, Sarker ZI, Ganjloo A. Optimization of ultrasound-assisted extraction of crude oil from winter melon (Benincasahispida) seed using response surface methodology and evaluation of its antioxidant activity, total phenolic content and fatty acid composition. Molecules 2012;17(10):11748-62.

38. Miller E, Malinowska K, Gałęcka E, Mrowicka M, Kędziora J. Rola flawonoidów jako przeciwutleniaczy w organizmie człowieka. Pol Merkur Lekarski 2008;24:556-60. 